\title{
The Great Recession and recent employment trends among secondary students in the United States
}

\author{
Jeremy Staff \\ The Pennsylvania State University \\ jus25@psu.edu \\ Monica Kirkpatrick Johnson \\ Washington State University \\ Megan E. Patrick, John E. Schulenberg \\ University of Michigan
}

(Received November 2013 Revised April 2014)

http://dx.doi.org/10.14301/llcs.v5i2.275

\section{Abstract}

The Great Recession had substantial effects on the labor market in the United States, as elsewhere. To what extent did secondary students' employment decline during this time? Which students are leaving the labor market? Are reductions in employment concentrated in particular jobs? To answer these questions, we use data from the Monitoring the Future study, an ongoing study of secondary students in the United States. More specifically, we examine recent trends in teenage employment using 6 cohorts each of $8^{\text {th }}, 10^{\text {th }}$, and $12^{\text {th }}$ graders (from 2006 to 2011, spanning before, during and after the Great Recession). Results show a gradual decline in school year employment since 2006, including the years after the official end of the recession. Employment during the school year is especially low among $8^{\text {th }}$ and $10^{\text {th }}$ graders, Hispanic and non-Hispanic Black youth, and students from disadvantaged backgrounds (based upon parental education), though the recent drop in work has varied little by population subgroups. The decline in employment is, however, concentrated among the oldest students, and working intensely (over 20 hours per week) has dropped more than working moderate hours. Students are more likely to babysit and do lawn work, and less likely to hold jobs in office, clerical, and sales positions than in years past. These patterns and recent shifts in job type suggest some degree of job replacement by older workers.

Keywords: teenage employment, Great Recession

\section{Introduction}

Adolescent employment has been a subject of great interest in the past three decades (see reviews by Mortimer, 2010; Staff, Messersmith, \& Schulenberg, 2009; Staff, Mont'Alvao, \& Mortimer, forthcoming). Scholars, educators, and policy makers alike have been interested in which teenagers are working for pay, how much of their time is allocated to it, and whether employment, especially among secondary students who are working long hours during the school year, has important short- and longterm consequences for young people's school achievement and social development. As such, it is important to understand whether the Great Recession in the United States affected the employment opportunities and experiences of middle and high school students.

Officially spanning from December 2007 to June 2009 in the United States, the Great Recession was marked by a countrywide decline in economic 
activity, increased rates of job loss and long-term unemployment, and reductions in individual wealth and household income, with far reaching effects (Garson, 2013; Grusky, Western, \& Wimer, 2011; Peck, 2012). The national unemployment rate among those 16 years of age or older, for instance, doubled from $5 \%$ to $10 \%$, peaking in October 2009 despite the recession's official end (U.S. Bureau of Labor Statistics, 2012). It has remained relatively high, dropping below $8 \%$ for the first time in September 2012. Unemployment rates are highest for the youngest workers (i.e., 16 to 19 year olds) and do not include youth who do not meet the official definition of unemployment but who may want to work if they could (U.S. Bureau of Labor Statistics, 2014).

Early employment experiences play an important role in the life course (Mortimer, 2003). By taking the long view of lives and how they are structured, scholars have shown how both the nature and amount of work change with age (Mortimer, 2003; Safron, Schulenberg, \& Bachman, 2001; Perreira, Harris, \& Lee, 2007; Steinberg \& Cauffman, 1995), as well as how early work experiences portend later trajectories of attainment, problem behaviors, and well-being (Bachman, Staff, O'Malley, Schulenberg, \& Freedman-Doan, 2011; Carr, Wright \& Brody, 1996; Mortimer \& Staff, 2004; Staff \& Mortimer, 2007). The life course is fundamentally structured in time and space, and the place of employment among secondary students may be changing. Students today may be less likely to work than in previous cohorts due to broad shifts in labor supply (e.g., changing high school graduation requirements may have made it harder for teenagers to combine school and work, and decrease their preferences to do so; see Smith, 2011, for a review) or labor demand (employers may prefer adult workers who are increasingly competing for what once were considered "teenage" jobs). It is likely that rates of employment among American secondary students were affected by the Great Recession, though it is also the case that teenage employment was on the decline before the recession hit (Smith, 2011; Staff et al., forthcoming). Thus, longer-term changes in the labor market, in education, and other factors are likely also involved.

The decision to enter the workforce is influenced by the young person's orientations and goals, so perhaps youth nowadays have less desire to work due to the increasing emphasis placed on attending and completing college (Goyette, 2008; Johnson \& Reynolds, 2013; Reynolds, Stewart, Sischo, \& McDonald, 2006). Furthermore, wanting and finding a job in the early life course, just as in older ages, is influenced by socio-demographic background. These characteristics are also likely to affect employers' selection among job seekers. As such, it is important to assess how gender, race/ethnicity, and socioeconomic background may shape overall trends in teenage employment while attending secondary school.

In this article, we use data from the ongoing Monitoring the Future (MTF) study to examine recent trends in employment among middle and high school students in the United States, charting change during the Great Recession and its aftermath. This ongoing project continues to collect data on large (approximately 17,000 students per grade), nationally representative samples of 8 th, 10th, and 12 th graders each year (Johnston, O'Malley, Bachman, \& Schulenberg 2013). Our use of the MTF allows us to examine whether rates of employment are changing in similar ways by gender, race/ethnicity, and socioeconomic background. In addition, we look at changes in educational goals and the types of work most in decline for insight into why employment among secondary students is diminishing, especially during the Great Recession.

\section{Teenage work in the United States}

Teenagers in the United States have a long history of working for pay, though for much of this history the teenagers who were working were no longer attending school (Greenberger \& Steinberg, 1986; Mortimer, 2003; Warren \& Cataldi, 2006). For example, among $16-17$ year old males in $1940,78 \%$ of those working were not attending school; by 1990 over $90 \%$ of workers in this group were also in school (Warren \& Cataldi, 2006). In both periods about half to two-thirds of 16-17 year old males were nonemployed students, but over time it became increasingly common for teenagers who did work to be in school simultaneously. Studies in the 1980s and 1990s indicated that nearly all U.S. adolescents enrolled in school were employed at some point during the school year (U.S. Department of Labor, 2000; Entwisle, Alexander, \& Olson, 2000) and work is 
now seen as a key developmental context of adolescence (Crosnoe \& Johnson, 2011). The transition "from school to work" is also recognized as involving an extensive period in which these roles actually overlap and may include movement back and forth between employment and returning to school (Staff \& Mortimer, 2007; Light, 2001). Given our study concerns those still in middle and high school, we focus on those who combine part-time work with fulltime school.

Scholars continue to debate and study whether holding a job during the school year is beneficial or detrimental to the personal development and longterm attainment of secondary students in the United States. As our study is not intended to address the short- and longer-term consequences of employment, we only briefly characterize this debate. From one perspective, employment may teach valuable skills applicable to working in adult life, as well as provide practice with money and time management, such that early work experience facilitates higher educational attainment and later income (e.g. Mortimer, 2003). From another perspective, employment detracts from schooling and facilitates substance use and other risky behaviors, especially when young workers spend long hours on the job (e.g., Bachman \& Schulenberg 1993; Monahan, Lee, \& Steinberg, 2011; Steinberg \& Dornbusch, 1991). Differences among adolescents prior to their employment may also explain what might appear as "consequences" of employment (Staff, Schulenberg, \& Bachman, 2010; Staff, Osgood, Schulenberg, Bachman, \& Messersmith, 2010). Importantly, research in this area has identified work intensity, or the number of hours per week that adolescents work, as a critical factor in whether employment is associated with beneficial or detrimental outcomes. As such, trends in the prevalence of intensive work, most often defined as working 20 or more hours per week during the school year, are important to track.

It is also important to identify the particular groups for which participation in employment is declining, as both the exposure and the risks and benefits of employment have not been shared equally among adolescents. Past research indicates that by the 1980s, gender no longer differentiated rates of employment in adolescence (Schoenhals, Tienda, \& Schneider, 1998; Warren \& Cataldi, 2006; Perreira et al., 2007), though research has not yet assessed whether gender differences in teenage employment have emerged in the wake of the Great Recession. Adolescents from lower socio-economic status families, or who are members of disadvantaged racial/ethnic groups, have had lower rates of employment, however, possibly due to reduced opportunity in local labor markets and other structural factors (D'Amico, 1984; Bachman \& Schulenberg, 1993; Steinberg \& Cauffman, 1995; Schoenhals et al., 1998; Warren \& Cataldi, 2006). Students from disadvantaged backgrounds may have been hit hardest by the Great Recession.

With respect to the risks and benefits of employment, these may depend on teens' reasons for working, the types of jobs and quality of work they are involved in, how they use their earnings, their developmental histories, and the broader social context (Apel et al., 2007; Entwisle, Alexander, \& Olson, 2005; Johnson, 2004; Lee \& Staff, 2007; Leventhal, Graber, \& Brooks-Gunn, 2001; Marsh, 1991; Marsh \& Kleitman, 2005; Newman, 1996). Substance use risks associated with spending long hours on the job, for example, are limited to nonHispanic White adolescents (Johnson, 2004; Bachman, Staff, O'Malley, \& Freedman-Doan, 2013). In fact, research shows that at-risk youth seem to benefit the most from heavier investments in work during adolescence (Apel et al., 2007; Staff \& Mortimer, 2007). It is possible that the groups that secure the most benefit and face the least risk from employment may be those whose participation is in the greatest decline.

\section{Why might teenage employment rates fall?}

Given the dramatic increase in the unemployment rate in the United States overall, it would not be surprising if teenagers' participation in work was reduced during the Great Recession. In a recent working paper, Smith (2011) reports substantial declines in employment among 16-17 year olds during the Recession, but also that employment among this age group has been trending downward since the 1980s. Reductions have occurred in employment for 16-17 year olds during each major recession since the 1980s without fully rebounding during recovery periods, and unemployment soared between 2007 and 2010 (Smith 2011). Whether 
these declines characterize the experience of teens at other ages is not known. Younger adolescents are often involved in more informal paid work (e.g., yardwork, babysitting) and work fewer hours, so that the recent economic downfall may have had less impact on younger teenagers.

Several hypotheses have been offered to explain the declines in work participation among teenagers (see review by Smith, 2011). Recent decades have seen the adult labor market increasingly divided between the "haves" and "have nots." While the earnings of those with college or graduate degrees have been steady or increasing, the earnings of those with less education - the vast majority of workershave eroded (Lemieux, 2006). The manufacturing sector has continued to decline, pushing more and more workers into the service sector (Morris \& Western, 1999). It may be that teenagers who seek employment during the school year are experiencing greater competition for jobs with older workersboth those in the normative employment years and also perhaps those who have delayed retirement. Rising immigration may be creating competition for jobs as well. The proportion of adults who are immigrants, rose in the 1990s and 2000s, and the proportion of both immigrant and native adults in "teenage" jobs has increased (Smith, 2011). As "middle" skill level jobs disappear, older workers who were or would have been in these jobs are being pushed into low skill and low paying jobs. Smith (2011) finds some support for the idea that adults are crowding teens out of the labor market, at least with respect to 16-17 year olds, suggesting that lower rates of youth employment are not entirely "voluntary."

Economic changes associated with the Great Recession may have exacerbated these trends toward lower participation in employment among secondary students. Massive job losses may have hit teenagers directly by downsizing or reduced hiring, but teens may also have been squeezed out even further as older displaced workers competed with them for the same jobs. Job losses in the U.S. economy were initially concentrated in specific job sectors including construction and manufacturing, but eventually touched nearly all sectors (Goodman \& Mance, 2011).

Consistent with this crowding out argument and the evidence to date, we expect work participation to have declined, particularly in recession years. Working teenagers may also have had to cut back on hours, so we would expect the largest declines among high intensity workers. In addition, if adolescents are indeed being crowded out by adults, declines in employment may have occurred mostly among older teens, who are in more direct competition with adults for jobs. We also expect to see stronger trends in the formal sector than in informal teenage jobs such as babysitting and yard work.

Teenagers enrolled in secondary school may also be investing less in employment in order to focus on college admission, perhaps especially among those who do not plan to rely on their own work earnings to fund college tuition. Adolescents' educational expectations have risen substantially over the past several decades, especially among those from lower social classes (Goyette, 2008; Reynolds et al., 2006; Schneider \& Stevenson, 1999). College has been viewed by parents and adolescents alike as more necessary, as the wage premium of college degree attainment has risen. In response, college enrollment has risen (Snyder, Tan \& Hoffman, 2006). As those teenagers who would have entered full-time work earlier in the past now set their sights on a college degree, investments in work may have changed. For those not anticipating higher education, it may have been strategic to invest in human and social capital accumulation though employment during high school (Staff \& Mortimer, 2007). As that group has become smaller, the prevalence of employment overall may have declined. College-bound youth may have shifted their time investments, spending their time instead in music lessons, sports, volunteer service, and academic pursuits that they anticipate will help with admission to their desired institutions of higher education. Non-working youth, particularly girls, do spend a little more time on these kinds of educational activities than employed youth (Smith, 2011).

Again, these trends may have been exacerbated by the Great Recession. The salience of university degrees may have grown, as a strategy for bolstering one's continued employability across the life course in more uncertain times. Consistent with this argument, focusing on the supply of teenage workers, we again expect employment rates to have fallen during recession years, especially among high intensity workers. In addition, this perspective leads 
to the expectation that adolescents planning to complete college degrees will have reduced their employment more than those expecting to enter the labor force without such credentials. If teenagers are manifesting a general disinclination to work, however, we would expect reduced employment to be evident across all ages of adolescence.

The current study is designed to assess current trends in employment, as well as the average number of hours worked, among middle and high school students in the United States. We investigate the following research questions:

1. What were the trends in school-year employment among secondary students across the period immediately before, during, and after the Great Recession?

2. Did these trends differ by key statuses including age, gender, socio-economic background (i.e. parent(s) education), and race/ethnicity?

3. Were employment trends linked to teens' educational goals?

4. Was change concentrated in certain types of jobs available to youth?

\section{Methods}

\section{The Monitoring the Future study}

Monitoring the Future (MTF) is an ongoing study of nationally-representative samples of middle and high school students in the US (Johnston et al., 2013). Each year, nationally representative samples of 8th, 10th, and 12th graders from approximately 135 public and private high schools and 155 middle schools across the US are selected using three-stage probability sampling procedures. Students completed paper questionnaires during school hours. Details regarding data collection are available elsewhere (Bachman, Johnston, O'Malley, \& Schulenberg, 2011).

MTF is a school-based study. Although the samples are nationally representative of adolescents in these grade levels, they are not necessarily representative of adolescents more broadly, which would include high school dropouts. As US students are legally required to attend school until at least age 16 (about $10^{\text {th }}$ grade), drop-out rates are typically calculated among 16-24 year olds. The dropout rate over the period between 2006 and 2011 remained under $10 \%$, with a slight downward trend evident (National Center for Education Statistics, 2014).
Employment rates may be higher among dropouts; because dropout is more common among older teens, employment rates for the $12^{\text {th }}$ grade sample in particular may underestimate overall employment rates at corresponding ages.

The present analyses are based on data from 6 recent MTF cohorts (from 2006 to 2011) of $8^{\text {th }}$ grade (modal age 14), $10^{\text {th }}$ grade (modal age 16 ) and $12^{\text {th }}$ grade respondents (modal age 18). Combining the multiple cohorts and grades, and excluding respondents who did not have valid data on selfreported employment, educational expectations, race/ethnicity, and parental education, reduced our sample size from 282,145 to 208,761 students. Approximately $4 \%$ of students had missing data regarding their school year employment, gender, and educational expectations. Just over $8 \%$ of students did not report their parents' educational attainment, and almost $17 \%$ were either missing data or reported a race/ethnicity other than Hispanic, Non-Hispanic Black, or Non-Hispanic White. With the exception of Table 2 (which was further limited to a random subset of employed youth who were asked questions regarding job type; $n=74,484$ ), all of the findings are based upon analyses of 208,761 students. Cases were weighted in all analyses to account for sampling design.

\section{Measures}

Each year, $8^{\text {th }}, 10^{\text {th }}$, and $12^{\text {th }}$ graders reported in the Spring, whether they were employed at any point during the school year, and if so, the average hours per week they worked (ranging on a 8-point scale from " 0 " to "more than 30 hours" per week). Among employed youth, we distinguished those who were employed "intensively" (i.e., 21 or more hours per week) from those who worked moderately (i.e., less than 21 hours per week). Employed $8^{\text {th }}$ and $10^{\text {th }}$ graders, as well as a random subset of employed $12^{\text {th }}$ grade youth, were then asked to report from a listing of job categories, the job that "comes closest to the kind of work you have done for pay." The jobs were combined into five categories: (1) informal jobs (babysitting or lawn work); (2) restaurant jobs (including fast-food); (3) farm or agriculture; (4) office, clerical, or sales jobs; and (5) a residual category captured "other" and "odd" jobs. If students had multiple jobs, they were instructed to choose the one in which they worked the most hours. 
Educational expectations indicated how likely respondents felt they were to graduate from a fouryear college (coded on a four-point scale from "definitely won't" to "definitely will"). Given the steep increase in college ambitions in recent decades, we distinguished youth who "definitely will" graduate from college from the others (i.e., "Definitely won't", " probably won't", and "probably will").

We also considered whether trends in teenage employment varied by gender (coded $0=$ male; $1=$ female), as well as parental education (coded $0=$ high school degree or less, including those who attended college but did not graduate; 1=college degree or higher). The MTF data set also includes detailed measures of race/ethnicity. To assess variation in employment across the three largest racial/ethnic groups, we present results for respondents coded as: (1) Hispanic (Mexican American, Cuban American, Puerto Rican, or other Latin American); (2) Non-Hispanic Black; or (3) NonHispanic White. Of the 208,761 respondents who had valid data on all measures, approximately $52 \%$ were female; $16 \%$ of respondents were Hispanic, $13 \%$ were non-Hispanic Black, and $71 \%$ were non-Hispanic White; $33 \%$ were in $8^{\text {th }}$ grade, $35 \%$ were in $10^{\text {th }}$ grade, and $32 \%$ were in $12^{\text {th }}$ grade; $55 \%$ of respondents' parent(s) had a college degree; and $64 \%$ of respondents expected that they would "definitely" graduate from college.

\section{Results}

\section{The reduction in teenage employment during the Great Recession}

Figure 1 shows the percentage of $8^{\text {th }}, 10^{\text {th }}$, and $12^{\text {th }}$ grade students who did not work during the school year, as well as those who worked moderately (i.e., averaged 1-20 hours per week) and more intensively (i.e., more than 20 hours per week) from 2006 to
2011. The cohorts are divided into three groups to assess employment rates in the years immediately before the Great Recession (i.e., 2006-2007 class cohorts), during the Great Recession (i.e., 2008-2009), and following the Great Recession (2010-2011). Figure 1 shows that employment rates declined during the Great Recession and its aftermath. For instance, in the years 2006 and 2007, 72\% of $8^{\text {th }}$ graders, $65 \%$ of $10^{\text {th }}$ graders, and $27 \%$ of $12^{\text {th }}$ graders did not work during the school year. In 2008 and $2009,75 \%$ of $8^{\text {th }}$ graders, $70 \%$ of $10^{\text {th }}$ graders, and $33 \%$ of $12^{\text {th }}$ graders did not work during the school year. The greatest changes occurred among $12^{\text {th }}$ graders and the smallest among $8^{\text {th }}$ graders. The percentage of non-working students continued to rise through the $2010-2011$ period. Approximately $78 \%$ of $8^{\text {th }}$ graders, $75 \%$ of $10^{\text {th }}$ graders, and $40 \%$ of $12^{\text {th }}$ graders in the 2010 and 2011 surveys were not currently employed and had not worked during the school year. The results suggest that teenagers have not returned to the workplace despite the recession's official end in 2009.

The loss of employment has been particularly high among $12^{\text {th }}$ graders who work intensively. For instance, before the recession, $28 \%$ of $12^{\text {th }}$ graders spent more than 21 hours per week working during the school year. By 2011 , only $17 \%$ of $12^{\text {th }}$ graders worked intensively. In contrast, the percentage of $12^{\text {th }}$ graders who worked moderately remained virtually unchanged (i.e., 45\% in 2006 and 2007; 45\% in 2008 and 2009; and 43\% in 2010 and 2011). Among $10^{\text {th }}$ graders, the decline in employment from $2006 / 2007$ to $2010 / 2011$ was more evenly distributed among moderate and intensive workers (the percentage employed intensively declined from $6 \%$ to $3 \%$; moderate work declined from approximately $29 \%$ to $22 \%)$. 


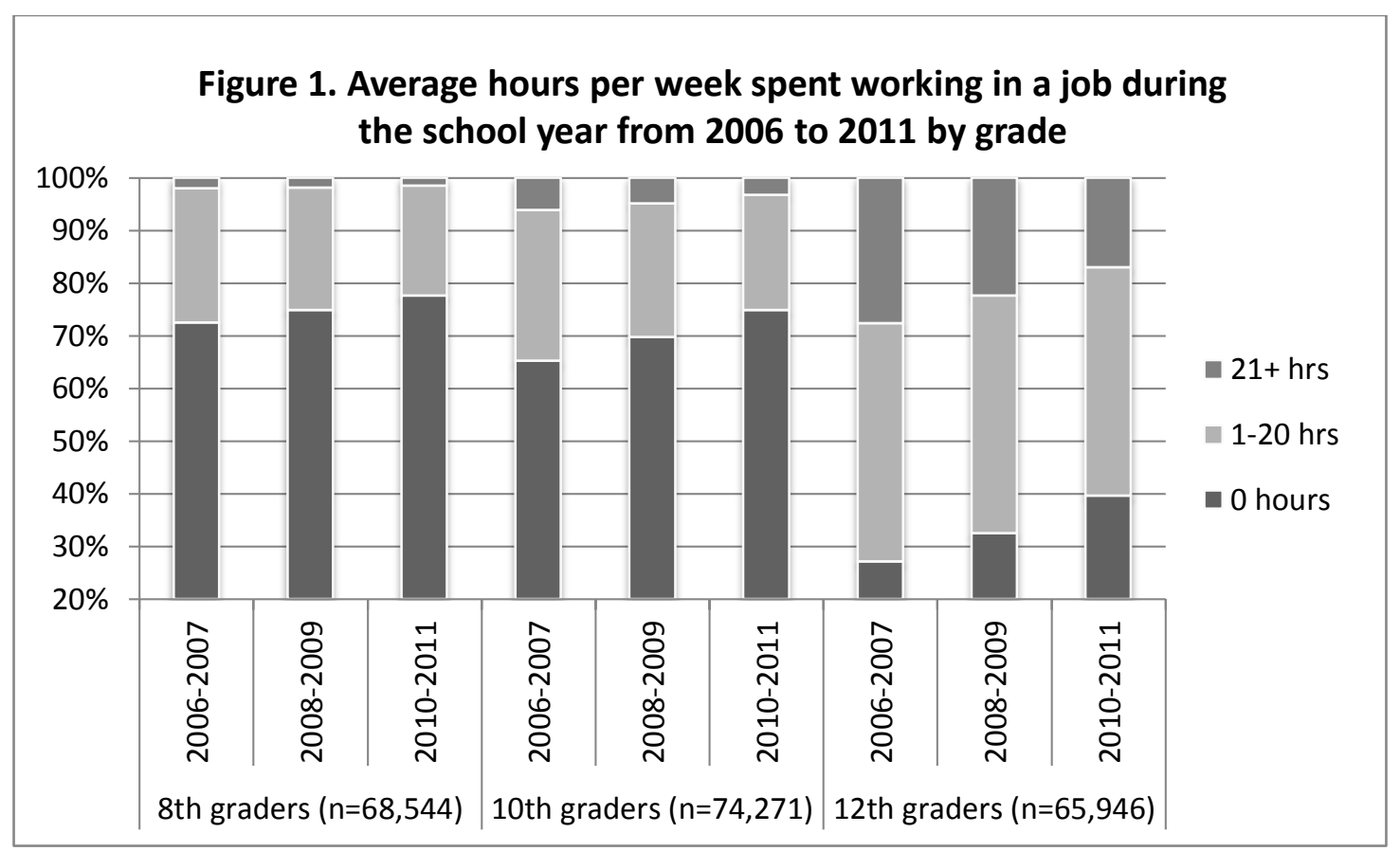

\section{Who is leaving?}

Research has long shown that racial minorities and youth from disadvantaged backgrounds (i.e., their parent(s) have low educational attainment, earnings, and household income) are less likely to hold jobs in adolescence than white youth and those from advantaged backgrounds. Since some population subgroups are more vulnerable to economic downturns than others, we are particularly interested in whether the Great Recession, as well as other economic changes, has altered gaps between population groups in rates of teenage employment. In Figure 2, we first show trends from 2006 to 2011 in the percentage of girls and boys (combining $8^{\text {th }}, 10^{\text {th }}$, and $12^{\text {th }}$ graders) who reported working zero hours during the school year, as well as those employed moderately and intensively. In all years since 2006, boys are more likely to be working than girls. Despite the high job loss among adult men in the United States during the Great Recession, the percentage of boys employed during the school years has remained approximately 4 to $5 \%$ higher than girls. In unlisted analyses, we found that this gender disparity in employment was most evident during the $8^{\text {th }}$ and $10^{\text {th }}$ grades of high school. By $12^{\text {th }}$ grade girls were slightly more likely to be employed than boys. Nevertheless, the gender disparity in teenage employment appears similar before, during, and after the Great Recession. Returning to Figure 2, we see little evidence that the overall decline in intensive and moderate employment varied by gender. From 2006 to 2011, girls and boys experienced similar drops in the number of hours worked during the school year. 


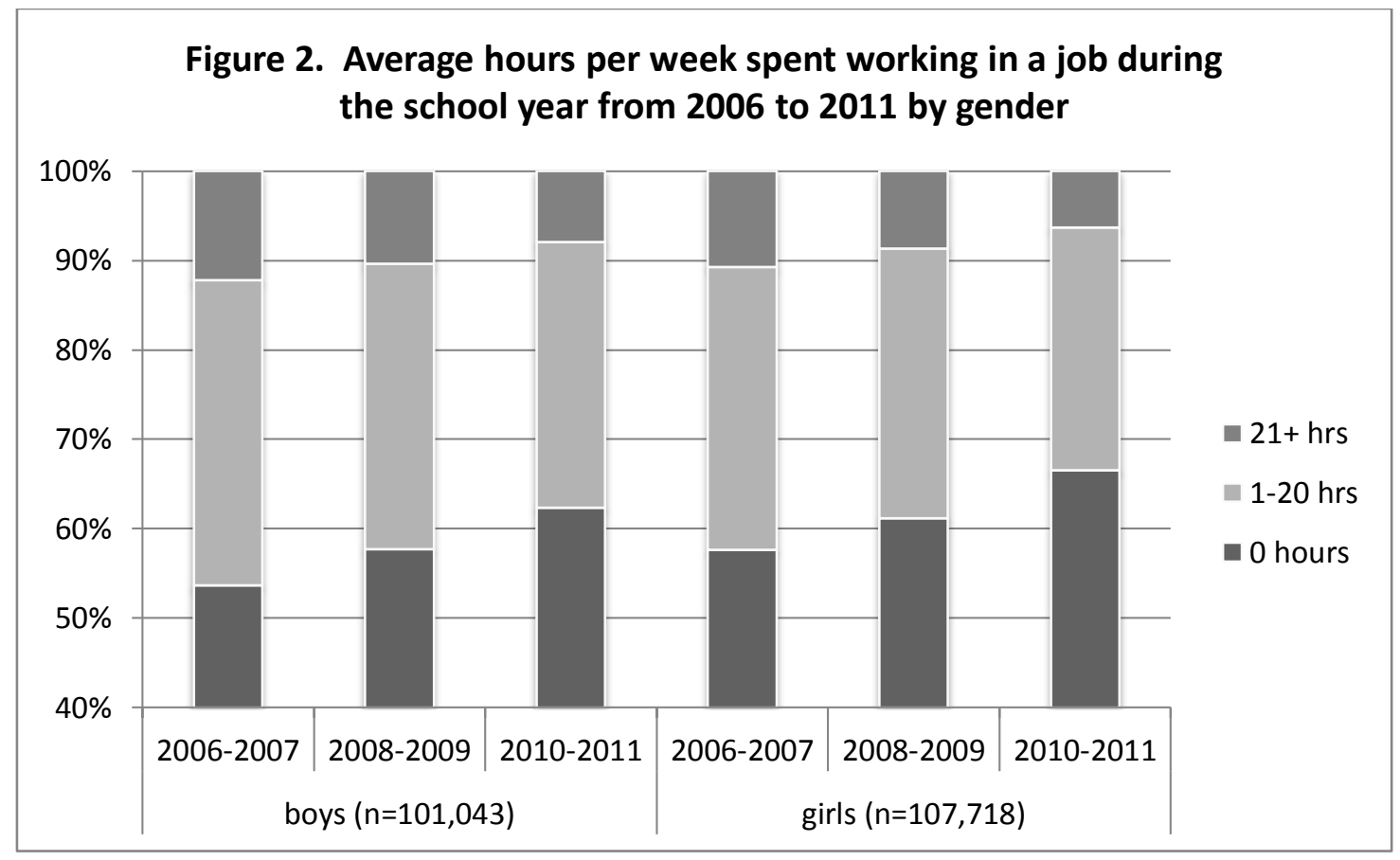

Figure 3 shows work hour trends during the school year from 2006 to 2011 separately for youth whose parents have some college education and those who do not. Before the Recession (2006-2007), as well as during the Recession (2008-2009), youth whose parent(s) had higher levels of education were only slightly more likely to be not working compared to youth from families with lower levels of education. In the years following the Great Recession (2010-2011), this slight difference in the percentage of nonworking youth had essentially disappeared (64.8\% compared to 64.3\%). From 2006 to 2011, the percentage of youth employed intensively in families with lower education declined by $6 \%$, compared to a $3 \%$ decline among youth in more advantaged families.

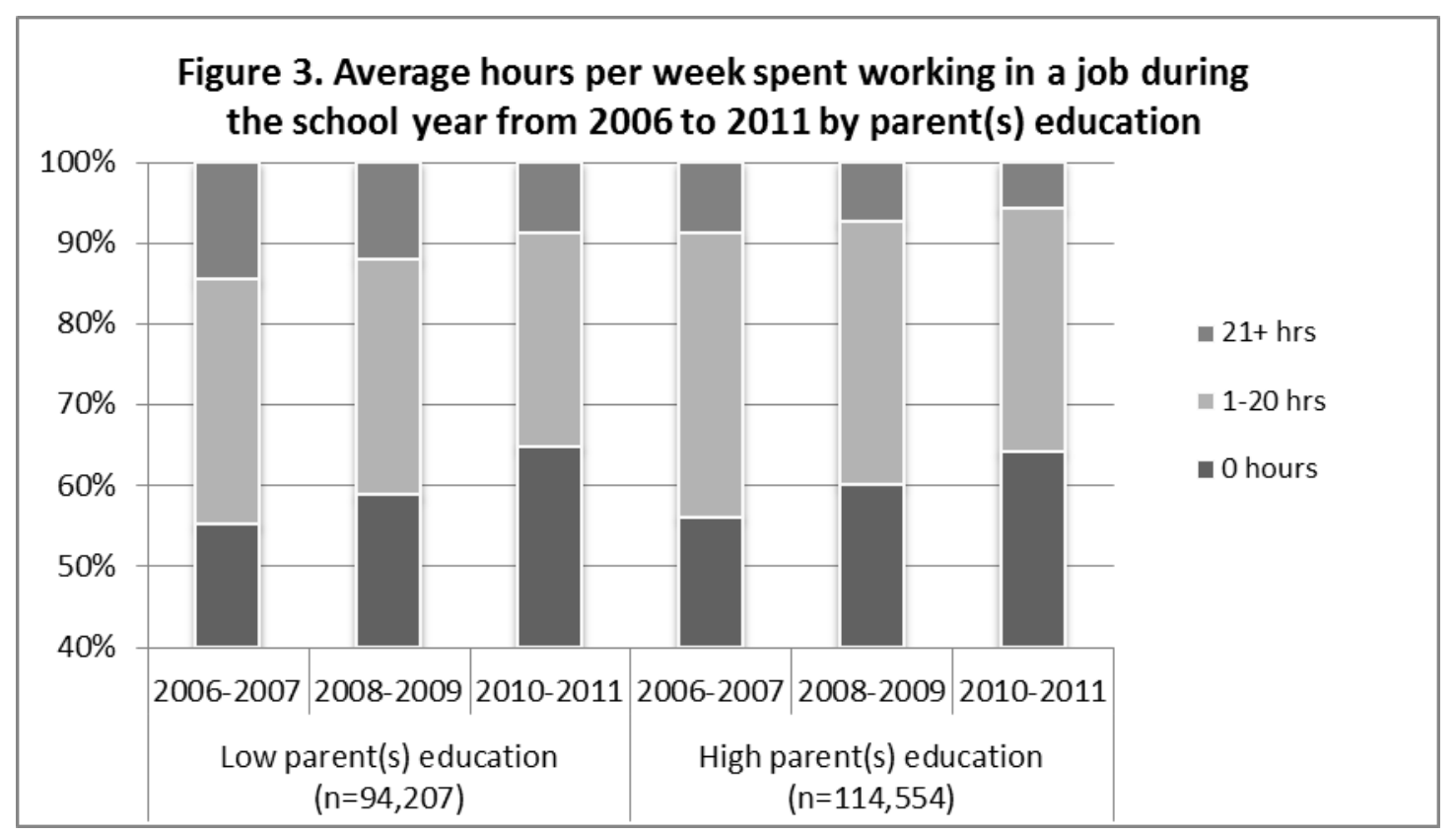




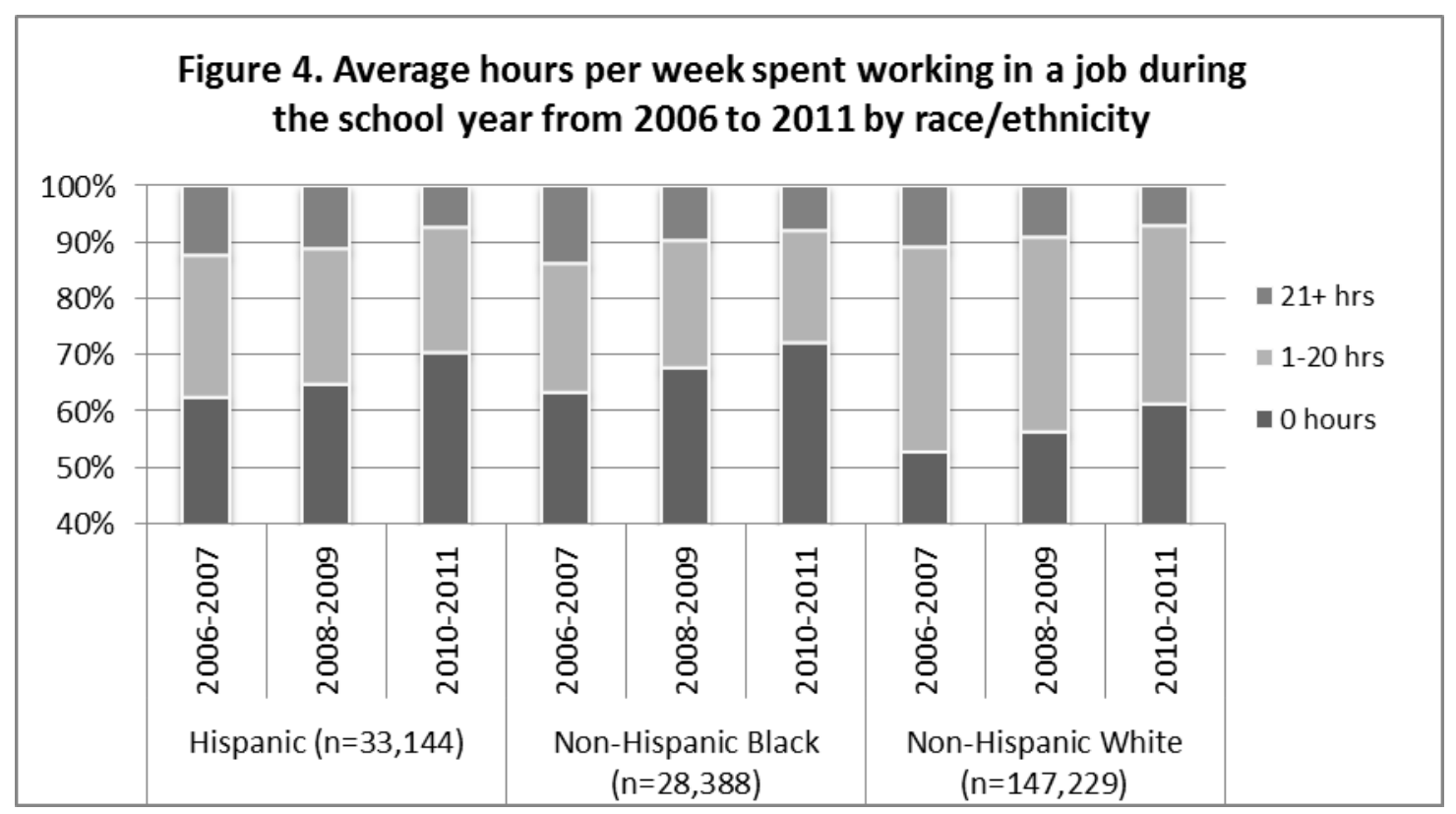

We conducted similar analyses in employment for Hispanic, non-Hispanic Black, and non-Hispanic White youth (these trends are shown in Figure 4). At all years, Black and Hispanic youth are much less likely to be in the labor force than Whites. By 2010-2011, for instance, 62\% of White youth were not working during the school year, compared to $70 \%$ of Hispanics and $72 \%$ of Blacks. Though less likely to be employed, at all years the percentage of Blacks and Hispanics employed intensively is higher than the percentage of whites employed intensively.

As mentioned in the introduction, one possible reason for the decline in youth employment concerns greater desire to attend college and greater competition to gain entry and scholarships into top colleges. That is, the strong desire for college would translate into more time devoted to preparing for college and less to working.
Thus, we compared work hours between those with and without an especially strong desire to graduate from a four-year college. As shown in Figure 5, although it was the case that those with a strong desire to graduate from a four-year college had higher non-working rates than those without, this difference was not greater in the years before, during, or following the Great Recession. However, the trends reveal a slightly steeper decline over time in intensive work among those who have more desire to graduate from college than among those with less desire. In 2006 and 2007, for instance, 15\% of youth with lower expectations worked intensively, compared to $9 \%$ who had stronger college expectations. By 2010-2011, only $9 \%$ of youth with low expectations had worked intensively, whereas $6 \%$ of youth with high expectations worked more than 20 hours per week. 


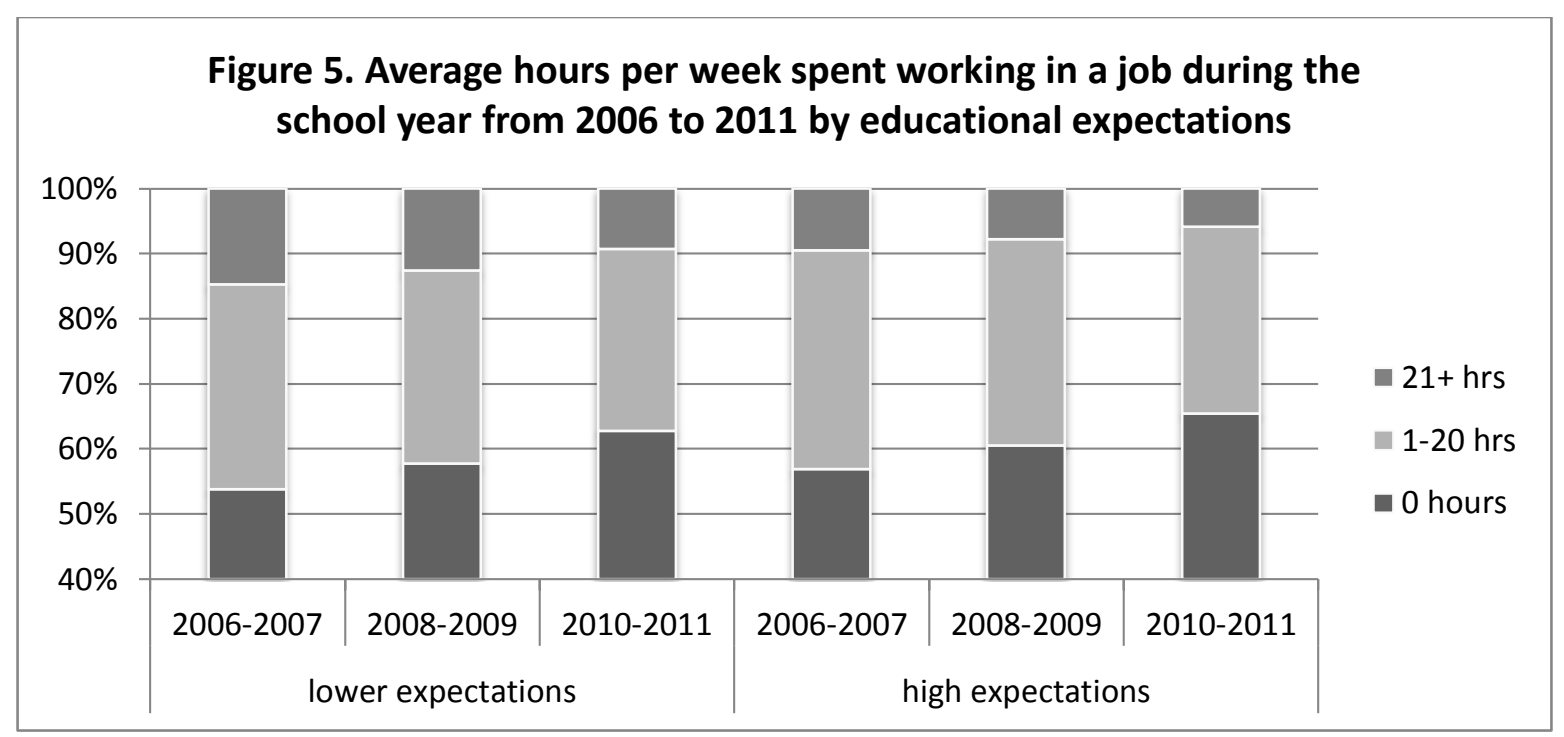

Overall, the figures provide some evidence that the decline in employment appears to have been highest among intensive workers. To more fully address this possibility, we estimated a multinomial logistic regression model including all recent MTF cohorts from 2006 to 2011 (208,761 students) to assess the impact of grade level, gender, race/ethnicity, parent(s) education, and educational expectations on the odds of working 0 hours (i.e., not being employed during the school year), working 1-20 hours per week, or working more than 20 hours per week. Table 1 shows odds ratios and 95\% confidence intervals for all comparisons of the outcome variable (sample size $=208,761$ respondents). As shown in the first column (which contrasts not working from moderate working), the odds of not working versus moderately working (i.e., 1-20 hours per week) are 19\% higher for girls than boys, controlling for the other covariates. The odds of not working versus moderately working are $89 \%$ and $60 \%$ higher for Hispanic and Black youth, respectively, than for white youth. Results also show that compared to $12^{\text {th }}$ graders, $10^{\text {th }}$ and especially $8^{\text {th }}$ graders are more likely to be not working during the school year. Youth whose parent(s) completed a post-secondary degree were slightly less likely to work during the school year, as were youth who definitely expected to graduate from college. Beyond these socio-demographic differences overall, the multivariate analyses document the recent decline in youth employment. For instance, the odds of not working, compared to working moderately, are 42\% higher from 2010 to 2011 compared to just five years earlier. 
Table 1. Odds ratios and $95 \%$ confidence intervals from a multinomial logistic regression model predicting work intensity during the school vear for recent MTF class cohorts

\begin{tabular}{|c|c|c|c|c|c|c|c|c|}
\hline & \multicolumn{3}{|c|}{0 vs $1-20$ hrs } & \multicolumn{3}{|c|}{$21+$ vs $1-20 \mathrm{hrs}$} & \multicolumn{2}{|c|}{$21+$ vs $0 \mathrm{hrs}$} \\
\hline & OR & $95 \%$ & & OR & $95 \%$ & & OR & $95 \% \mathrm{Cl}$ \\
\hline Girl (vs. boy) & 1.19[ & 1.16 & $1.22]$ & 0.88[ & 0.85 & 0.92 ] & 0.74[ & $0.71,0.77]$ \\
\hline \multicolumn{9}{|l|}{ Race/ethnicity } \\
\hline White & \multicolumn{3}{|c|}{ referent } & \multicolumn{3}{|c|}{ referent } & \multicolumn{2}{|c|}{ referent } \\
\hline Black & 1.89[ & 1.82 & $1.96]$ & 1.73[ & 1.63 & $1.83]$ & 0.92[ & $0.87,0.97]$ \\
\hline Hispanic & 1.60[ & 1.54 & $1.66]$ & 1.41[ & 1.33 & 1.49 ] & 0.88[ & $0.83,0.93]$ \\
\hline \multicolumn{9}{|l|}{ Grade } \\
\hline 8th graders (ages 13-14) & 4.42[ & 4.29 & $4.56]$ & 0.15[ & 0.14 & $0.17]$ & 0.03[ & $0.03,0.04]$ \\
\hline 10th graders (ages 15-16) & 3.84[ & 3.74 & $3.95]$ & 0.37[ & 0.36 & $0.39]$ & 0.10[ & $0.09,0.10]$ \\
\hline 12th graders (ages 17-18) & \multicolumn{3}{|c|}{ referent } & \multicolumn{3}{|c|}{ referent } & \multicolumn{2}{|r|}{ referent } \\
\hline \multicolumn{9}{|l|}{ Parent(s) highest education } \\
\hline $\begin{array}{l}\text { College degree or higher (vs. } \\
\text { high school degree or less) }\end{array}$ & 0.95[ & 0.93 & $0.98]$ & 0.64[ & 0.61 & $0.67]$ & 0.67[ & $0.64,0.70]$ \\
\hline \multicolumn{9}{|l|}{ Educational expectations } \\
\hline High expectations (vs lower) & 0.96[ & 0.94 & $0.99]$ & 0.69[ & 0.67 & $0.72]$ & 0.72[ & $0.69,0.75]$ \\
\hline \multicolumn{9}{|l|}{ Cohort } \\
\hline $2006-2007$ & & referent & & & referent & & & eferent \\
\hline $2008-2009$ & 1.16[ & 1.12 & $1.19]$ & 0.83[ & 0.79 & $0.87]$ & 0.72[ & $0.69,0.75]$ \\
\hline $2010-2011$ & 1.42[ & 1.38 & $1.46]$ & 0.65[ & 0.62 & 0.69 ] & 0.46[ & $0.44,0.48]$ \\
\hline
\end{tabular}

In columns 2 and 3 , which contrast intensive workers with those employed moderately or not at all, respectively, we see that recent cohorts of teenagers are significantly less likely to spend long hours working. Compared to 2006-2007, youth in 20102011 were $35 \%$ and $54 \%$ less likely to work intensively than moderate and non-workers, respectively. The results also suggest that employed Blacks and Hispanics were more likely than whites to average more than $\mathbf{2 0}$ hours per week on the job, though they were less likely than whites to be employed (either intensively or moderately). Furthermore, although youth who held high college expectations and whose parents had relatively high levels of education were less likely to be employed, they were more likely to limit their hours of work during the school year. Boys and youth in younger grades were less likely to be employed than girls and older youth, but when they did work they were more likely to spend long hours on the job.

To test whether the effects of these predictor variables have recently changed, in models (not shown here but available from the authors upon request) we estimated separate models for the cohorts before, during, and after the Great Recession, and then used z-tests to assess the equality of the estimates. We found little evidence that the associations between work hours and gender, parent(s) education, race/ethnicity, and educational expectations varied over the six year period. We did find that the association between grade level and employment has varied somewhat across cohorts, consistent with our discussion of Figure 1. Differences in school year employment by grade level have 
converged in recent years, primarily due to the increase in $10^{\text {th }}$ and $12^{\text {th }}$ graders who are no longer working during the school year.

\section{What jobs have seen change?}

An additional explanation regarding why teenage employment has declined in recent years, as discussed earlier, is the increasing competition from adult workers. If this competition hypothesis were true, we would expect to see youth leaving jobs that offer more opportunities for skill development, and moving more into typical teenage jobs. We find some evidence in support of this conjecture. Table 2 shows changes in the types of jobs acquired by $8^{\text {th }}, 10^{\text {th }}$, and $12^{\text {th }}$ graders from 2006 to 2011 . Compared to the $8^{\text {th }}$ graders, rates of employment in informal jobs (i.e., babysitting, yard work, etc.) are lower by the $12^{\text {th }}$ and $10^{\text {th }}$ grades, but informal work has increased in prevalence for all grades. For instance, $70 \%$ of $8^{\text {th }}$ graders, $57 \%$ of $10^{\text {th }}$ graders, and $16 \%$ of $12^{\text {th }}$ graders in 2010-2011 worked in an informal job, percentages that were one to nine points higher than in 20062007. Compared to the pre-recession period, secondary students in 2010-2011 were less likely to be employed as store clerks or salespersons or in office or clerical jobs (dropping from $29 \%$ to $24 \%$ for $12^{\text {th }}$ graders and from $9 \%$ to $6 \%$ for $10^{\text {th }}$ graders). Tenth graders are also less likely to be employed in restaurants (dropping from $15 \%$ to $9 \%$ ).

Table 2. Types of jobs secondary students are holding from 2006 to 2011 by grade

$$
\text { 8th graders 10th graders 12th graders }
$$

2006-20072008-2009010-201D006-20072008-2009010-201D006-20072008-2009010-2011

\begin{tabular}{lccccccccc}
\hline Informal & $69 \%$ & $69 \%$ & $70 \%$ & $48 \%$ & $51 \%$ & $57 \%$ & $13 \%$ & $13 \%$ & $16 \%$ \\
Restaurant & $3 \%$ & $4 \%$ & $3 \%$ & $15 \%$ & $15 \%$ & $9 \%$ & $30 \%$ & $33 \%$ & $32 \%$ \\
Farm or agriculture & $4 \%$ & $5 \%$ & $6 \%$ & $5 \%$ & $5 \%$ & $5 \%$ & $3 \%$ & $3 \%$ & $3 \%$ \\
Office, clerical, or sales & $2 \%$ & $2 \%$ & $2 \%$ & $9 \%$ & $7 \%$ & $6 \%$ & $29 \%$ & $27 \%$ & $24 \%$ \\
Other & $21 \%$ & $20 \%$ & $19 \%$ & $24 \%$ & $22 \%$ & $23 \%$ & $25 \%$ & $24 \%$ & $25 \%$ \\
\hline Total & $100 \%$ & $100 \%$ & $100 \%$ & $100 \%$ & $100 \%$ & $100 \%$ & $100 \%$ & $100 \%$ & $100 \%$
\end{tabular}

Sample size $=74,484$

\section{Discussion}

We set out to consider the extent to which US teenage employment changed during the Great Recession, and how these changes were moderated by socio-demographics, by student educational goals, and by type of job. What we found is that work during the school year is disappearing among 8 th, $10^{\text {th }}$, and $12^{\text {th }}$ grade students in the United States. Only 20 years ago, 3 out of 4 of the nation's high school seniors worked during the school year, as did approximately $40 \%$ of $8^{\text {th }}$ and $10^{\text {th }}$ graders (Staff et al., forthcoming). Today, the corresponding rates are $60 \%$ and $25 \%$, respectively. The percentage of non-working secondary students clearly climbed during the Great Recession, just as it did for adults (Grusky et al., 2011). But what is especially notable is that teenagers today do not seem to be returning to the labor market, despite the official end of the economic recession in 2009.
Why are teenagers not returning to the labor market in these better economic times? As we reviewed in the introduction, Smith (2011) offered several reasons why teenagers could be leaving work. One reason is that youth, often the last hired and the first fired, are increasingly being squeezed out of the labor market due to increased competition from adults, who typically have more experience and are viewed as more dependable and trustworthy by employers. The concentration of employment declines at older ages in adolescence, and of working longer hours, are consistent with this crowding-out explanation. Our analysis indicates the loss of employment was most concentrated among $12^{\text {th }}$ graders working more than 20 hours per week. In our analyses, we also found that teenagers in recent years are less likely to be in the semi-skilled jobs that would be more attractive to adults, such as working in sales, as a clerk, or in an office, and are more likely to be in the more informal type jobs (such as babysitting or 
mowing lawns), typically filled by adolescents. Although these changes may suggest that adolescents are drifting more toward typical "teen-jobs" and away from typical "adult-jobs," it may also be true that store clerk jobs are less common, given the decline in brickand-mortar stores, the increase in self-service checkout, and the overall drop in retail trade during the Great Recession (U.S. Bureau of Labor Statistics, 2012).

We find less support for the notion that youth are leaving the labor market due to supply-side factors. For instance, the well-documented increase in college ambitions does not appear to be driving youth away from paid work. As we show here, youth with especially high educational expectations are not leaving work at appreciably higher rates than youth with lower expectations. In fact, the reduction in working intensively is steeper among those with lower educational expectations. Moreover, we see only small differences in recent employment trends among youth who have highly educated parents (who are the most likely to attend and graduate from college) and those who do not. These trends suggest that rising ambitions and educational policies designed to improve learning and keep youth in school are not necessarily driving the decline in youth work.

These employment trends will be considered problematic or offering relief to scholars and policy makers, depending on their position in the ongoing debates about the consequences of employment. Our analyses do not contribute to this debate directly, however they do provide important context. Intensive employment of working 20 or more hours per week, which tends to be the most controversial, is declining more than moderate employment. In addition, gaps in employment and work intensity, along with important status characteristics including gender, race/ethnicity and socio-economic background, have not changed with the overall pull-back from employment. These gaps have not narrowed, but neither have they been exacerbated.

An important question is what else young people are doing with their time, as working rates are declining. Are these alternatives for time-use any more or less beneficial in terms of developmental, health, and educational outcomes? To the extent that youth are interning or volunteering, providing community service, or getting more involved in extra-curricular and academic activities, this would suggest less reason for worry. In contrast, to the extent that youth are spending more time in unproductive activities and settings, yielding little benefit in terms of human capital development, then the decline in work becomes more worrisome. It is even more problematic if youth are using their increased discretionary time to engage in unsupervised leisure activities that engender trouble-making and deviance. Thus it would be desirable for future research to address trends in time use among teenagers.

In addition, cross-national comparative research is needed. In this research, we focused on school year employment trends in the United States among $8^{\text {th }}$, $10^{\text {th }}$, and $12^{\text {th }}$ grade students. Worldwide there has been a decline in adolescent and child labor, and future research should assess the factors driving these changes in other countries, especially in developing economies (Staff et al., forthcoming). Future research should use longitudinal data and more sophisticated methodologies to control for the many plausible supply and demand side factors, as well as pre-existing and unobserved influences, driving these trends in teenage employment. For instance, what influence do statewide changes in graduation requirements and legislation aimed at child labor have on youth employment? How have recent changes in parental employment impacted the labor market participation of their children? These are important questions for future research. Research should also chart changes in the quality of youth employment. Here we showed recent shifts in job type among teenagers, but research has not assessed whether learning and vocational development opportunities have also diminished in recent years. Perhaps many youth are not working because the jobs available to them have little career relevance and lack potential for skill development.

In summary, it is clear that youth employment in the United States declined during the years of the Great Recession and its aftermath. For many teenagers, these early employment experiences can have a powerful influence in the life course. Understanding the long-term developmental, educational, vocational, and social implications of this broad departure from youth work will be a focus of our future research endeavors. 


\section{Acknowledgements}

This article was prepared for the Special Section on "Youth, Economic Hardship, and the Worldwide Great Recession" in Longitudinal and Life Course Studies. Prior versions of this manuscript were presented at the 2011 meeting of the Society for Longitudinal and Life Course Studies and the 2012 meeting of the Society for Research on Adolescence. Funding for this research was provided by a Mentored Research Scientist Development Award in Population Research from the National Institute of Child Health and Human Development (HD054467) to the first author. Results presented in this article are based upon analyses of data from the Monitoring the Future study, which is supported by a grant from the National Institute on Drug Abuse (R01-DA01411).

\section{References}

Apel, R., Bushway, S., Brame, R., Haviland, A., Nagin, D., \& Paternoster, R. (2007). Unpacking the relationship between adolescent employment and antisocial behavior: A matched samples comparison. Criminology, 45, 67-97. http://dx.doi.org/10.1111/i.1745-9125.2007.00072.x

Bachman, J. G., Johnston, L. D., O'Malley, P. M. \& Schulenberg, J. E. (2011). The Monitoring the Future project after thirty-seven years: Design and procedures (Monitoring the Future Occasional Paper No. 76). Ann Arbor, MI: Institute for Social Research.

Bachman, J. G., Staff, J., O'Malley, P, \& Freedman-Doan, P. (2013). Race-ethnicity and socioeconomic status moderate how student paid work intensity is related to scholastic performance and substance use. Developmental Psychology 49:2125-2134. http://dx.doi.org/10.1037/a0031464

Bachman, J. G., Staff, J., O'Malley, P., Schulenberg, J. E., \& Freedman-Doan, P. (2011). Twelfth-grade student work intensity linked to later educational attainment and substance use: New longitudinal evidence. Developmental Psychology, 47, 344-363. http://dx.doi.org/10.1037/a0021027

Bachman, J. G., \& Schulenberg, J. E. (1993). How part-time work intensity relates to drug use, problem behavior, time use, and satisfaction among high school seniors: Are these consequences or merely correlates? Developmental Psychology, 29, 220-235. http://dx.doi.org/10.1037/0012-1649.29.2.220

Carr, R., Wright, J., \& Brody, C. (1996). Effects of high school work experience a decade later: Evidence from the National Longitudinal Study. Sociology of Education, 69, 66-81. http://dx.doi.org/10.2307/2112724

Crosnoe, R., \& Johnson, M. K. (2011). Research on adolescence in the $21^{\text {st }}$ century. Annual Review of Sociology, 37, 439-460. http://dx.doi.org/10.1146/annurev-soc-081309-150008

D'Amico, R. (1984). Does employment during high school impair academic progress? Sociology of Education, 57, 152-164. http://dx.doi.org/10.2307/2112599

Entwisle, D. R., Alexander, K. L., \& Olson, L. S. (2000). Early work histories of urban youth. American Sociological Review, 65, 279-297. http://dx.doi.org/10.2307/2657441

Entwisle, D. R., Alexander, K. L., \& Olson, L. S. (2005). Urban teenagers: Work and dropout. Youth and Society, 37, 3-32. http://dx.doi.org/10.1177/0044118X04268313

Garson, B. (2013). Down the up escalator: How the 99\% live in the great recession. New York: Doubleday.

Goodman, C.J., \& Mance, S.M. (2011). Employment loss and the 2007-09 recession: An overview. Monthly Labor Review, 134, 3-12. Retrieved from http://www.bls.gov/opub/mlr/2011/04/art1full.pdf

Goyette, K. A. (2008). College for some to college for all: Social background, occupational expectations, and educational expectations over time. Social Science Research, 37, 461-484. http://dx.doi.org/10.1016/i.ssresearch.2008.02.002

Greenberger, E., \& Steinberg, L. D. (1986). When teenagers work: The psychological and social costs of teenage employment. New York, NY: Basic Books.

Grusky, D. B., Western, B., and Wimer, C. (Eds.). (2011). The great recession. New York, NY: Russell Sage Foundation.

Johnson, M. K. (2004). Further evidence on adolescent employment and substance use: Differences by race and ethnicity. Journal of Health and Social Behavior, 45, 187-197. http://dx.doi.org/10.1177/002214650404500205

Johnson, M. K., \& Reynolds, J. (2013). Educational expectation trajectories and attainment in the transition to adulthood. Social Science Research, 42, 818-835. http://dx.doi.org/10.1016/i.ssresearch.2012.12.003

Johnston, L. D., O'Malley, P. M., Bachman, J. G., \& Schulenberg, J. E. (2013). Monitoring the Future national survey results on drug use, 1975-2012: Volume I, Secondary school students. Bethesda, MD: National Institute on Drug Abuse. 
Lee, J. C., \& Staff, J. (2007). When work matters: The varying impact of adolescent work intensity on high school drop-out. Sociology of Education, 80, 158-178. http://dx.doi.org/10.1177/003804070708000204

Lemieux, T. (2006). Postsecondary education and increased wage inequality. American Economic Review, 96, 195-199. http://dx.doi.org/10.1257/000282806777211667

Leventhal, T., Graber, J. A., \& Brooks-Gunn, J. (2001). Adolescent transitions to young adulthood: Antecedents, correlates, and consequences of adolescent employment. Journal of Research on Adolescence, 11, 297323. http://dx.doi.org/10.1111/1532-7795.00014

Light, A. (2001). In-school work experience and the returns to schooling. Journal of Labor Economics, 19, 65-93. http://dx.doi.org/10.1086/209980

Marsh, H. W. (1991). Employment during high school: Character building or subversion of academic goals? Sociology of Education, 64, 172-189. http://dx.doi.org/10.2307/2112850

Marsh, H. W., \& Kleitman, S. (2005). Consequences of employment during high school: Character building, subversion of academic goals, or a threshold? American Educational Research Journal, 42, 331-369. http://dx.doi.org/10.3102/00028312042002331

Monahan, K. C., Lee, J. M., \& Steinberg, L. (2011). Revisiting the impact of part-time work on adolescent adjustment: Distinguishing between selection and socialization using propensity score matching. Child development, 82(1), 96-112. http://dx.doi.org/10.1111/j.1467-8624.2010.01543.x

Morris, M., \& Western, B. (1999). Inequality in earnings at the close of the twentieth century. Annual Review of Sociology, 25, 623-657. http://dx.doi.org/10.1146/annurev.soc.25.1.623

Mortimer, J. T. (2003). Working and growing up in America. Cambridge, MA: Harvard University Press.

Mortimer, J. T. (2010). The benefits and risks of adolescent employment. Prevention Researcher, 17, 8-11.

Mortimer, J. T., \& Staff, J. (2004). Early work as a source of developmental discontinuity during the transition to adulthood. Development and Psychopathology, 16, 1047-1070. http://dx.doi.org/10.1017/S0954579404040131

National Center for Education Statistics. (2014). The Condition of Education 2013. NCES 2013-037. US Department of Education. Retrieved from http://nces.ed.gov/programs/coe/pdf/coe coj.pdf.

Newman, K. S. (1996). Working poor: Low-wage employment in the lives of Harlem youth. In J. A. Graber, J. Brooks-Gunn, \& A. C. Petersen (Eds.), Transitions through Adolescence: Interpersonal Domains and Context (pp. 323-343). Mahwah, NJ: Lawrence Erlbaum.

Peck, D. (2012). Pinched: How the great recession has narrowed our futures and what we can do about it. Random House Digital, Inc.

Perreira, K. M., Harris, K. M., \& Lee, D. (2007). Immigrant youth in the labor market. Work and Occupations, 34, 5-34. http://dx.doi.org/10.1177/0730888406295394

Reynolds, J., Stewart, M., Sischo, L., \& McDonald, R. (2006). Have adolescents become too ambitious? High school seniors' educational and occupational plans, 1976-2000. Social Problems, 53, 186-206. http://dx.doi.org/10.1525/sp.2006.53.2.186

Safron, D., Schulenberg, J. E., \& Bachman, J. G. (2001). Part-time work and hurried adolescence: The links among work intensity, social activities, health behaviors, and substance use. Journal of Health and Social Behavior, 42, 425-449. http://dx.doi.org/10.2307/3090188

Schneider, B., \& Stevenson, D. (1999). The ambitious generation: America's teenagers, motivated but directionless. New Haven, CT: Yale University Press.

Schoenhals, M., Tienda, M., \& Schneider, B. (1998). The educational and personal consequences of adolescent employment. Social Forces, 77, 723-762. http://dx.doi.org/10.1093/sf/77.2.723

Smith, C. L. (2011). Polarization, immigration, education: What's behind the dramatic decline in youth employment? Working paper in the Finance and Economics Discussion Series, Divisions of Research and Statistics and Monetary Affairs, Federal Reserve Board, Washington, D.C.

Snyder, T. D., Tan, A. G., \& Hoffman, C. M. (2006). Digest of Education Statistics 2005, (NCES 2006-030). Washington, DC: National Center for Education Statistics, U.S. Department of Education.

Staff, J., \& Mortimer, J. T. (2007). Educational and work strategies from adolescence to early adulthood: Consequences for educational attainment. Social Forces, 85, 1169-1194. http://dx.doi.org/10.1353/sof.2007.0057

Staff, J., Messersmith, E. E., \& Schulenberg, J. E. (2009). Adolescents and the world of work. In R. Lerner \& L. Steinberg (Eds.), Handbook of Adolescent Psychology, $3^{\text {rd }}$ Edition (pp. 270-313). New York: John Wiley and Sons. http://dx.doi.org/10.1002/9780470479193.adlpsy002009

Staff, J., Osgood, D. W., Schulenberg, J. E., Bachman, J. G., \& Messersmith, E. E. (2010). Explaining the relationship between employment and juvenile delinquency. Criminology, 48, 1101-1131. http://dx.doi.org/10.1111/i.1745-9125.2010.00213.x 
Staff, J., Schulenberg, J. E., \& Bachman, J. G. (2010). Adolescent work intensity, school performance, and academic engagement. Sociology of Education, 83, 183-200. http://dx.doi.org/10.1177/0038040710374585

Staff, J., Mont'Alvao, A., \& Mortimer, J. T. (Forthcoming). Children at Work. In M. Bornstein \& T. Leventhal (Eds.), Handbook of Child Psychology and Developmental Science, Volume 4: Ecological Settings and Processes in Developmental Systems.

Steinberg, L., \& Cauffman, E. (1995). The impact of employment on adolescent development. Annals of Child Development, 11, 131-166.

Steinberg, L., \& Dornbusch, S. M. (1991) Negative correlates of part-time employment during adolescence: Replication and elaboration. Developmental Psychology, 27, 304-313. http://dx.doi.org/10.1037/00121649.27.2.304

Steinberg, L. D., Fegley, S., \& Dornbusch, S. M. (1993). Negative impact of part-time work on adolescent adjustment: Evidence from a longitudinal study. Developmental Psychology, 29, 171-180. http://dx.doi.org/10.1037/0012-1649.29.2.171

U.S. Department of Labor. (2000). Report on the youth labor force. Washington, DC: U.S. Government Printing Office.

U.S. Bureau of Labor Statistics. (2012). The Recession of 2007-2009. Retrieved from http://www.bls.gov/spotlight/2012/recession/pdf/recession bls spotlight.pdf

U.S. Bureau of Labor Statistics. (2014). The Employment situation-March 2014. Retrieved from http://www.bls.gov/news.release/pdf/empsit.pdf

Warren, J. R., \& Cataldi, E. F. (2006). A historical perspective on high school students' paid employment and its association with high school dropout. Sociological Forum, 21, 113-143.

http://dx.doi.org/10.1007/s11206-006-9005-7 